\title{
Current methods of rehabilitation after arthroscopic reconstruction of the anterior cruciate ligament of the knee joint (review of literature)
}

\author{
I.F. Akhtyamov ${ }^{1}$, V.I. Aidarov ${ }^{2}$, E.R. Khasanov ${ }^{1}$ \\ ${ }^{1}$ Kazan State Medical University, Kazan, Russian Federation \\ ${ }^{2}$ Republican Clinical Hospital, Kazan, Russian Federation
}

\begin{abstract}
Introduction The leading method for treating patients with injuries of the anterior cruciate ligament is its reconstruction. Although this operation is a common procedure, the issues of rehabilitation have not been fully studied. The aim of study Collection and analysis of available published studies on current methods of rehabilitation treatment after arthroscopic reconstruction of the anterior cruciate ligament. Materials and methods We analyzed the publications that were devoted to current methods of rehabilitation treatment of patients after arthroscopic reconstruction of the anterior cruciate ligament. The materials were searched for in the PubMed and Web of Science databases using the keywords "anterior cruciate ligament reconstruction", "anterior cruciate ligament rehabilitation". Inclusion criteria were compliance with the general topic, relevance, introduction of new rehabilitation treatments. Studies published earlier than the last 10 years were excluded. Results The analysis found that the main rehabilitation treatments used in patients after reconstruction of the anterior cruciate ligament are of protective character (wearing a functional orthosis or other immobilizing appliance, dosed walking with crutches) and physical activity (complex of exercises, swimming). The most effective way to prevent contractures is early activation of the limb and the maintenance of muscle tone. In turn, the main task of immobilization is prevention or relief of pain. Our study proposes the authors' methods of rehabilitation which can be used for restorative treatment and accelerate the process of ligament repair. The work includes rehabilitation procedures performed at home after reconstruction of the anterior cruciate ligament under the supervision of a rehabilitation instructor. Discussion Rehabilitation of patients after reconstruction of the anterior cruciate ligament is a necessary complement to surgical treatment. Fast recovery of patients and a full return to an active lifestyle depend on a proper rehabilitation program.
\end{abstract}

Keywords: anterior cruciate ligament reconstruction, rehabilitation treatment, arthroscopy

\section{INTRODUCTION}

Rupture of the anterior cruciate ligament (ACL) has been reported as one of the most common injuries of the knee joint $[1,2]$. It occurs in $62 \%$ of knee injuries. The mechanism of trauma is associated with sharp active repetitive movements in the joint (jumping, running), more common in young people involved in sports activities [2-6]. At the same time, this type of injury is not typical exclusively for athletes and may also occurs in domestic and road accidents associated with sudden sharp twisting, hyperextension or flexion of the knee joint, as well as due to a direct blow to the knee joint or lower leg [7-9 ]. Thanks to the high-tech medical assistance program, this type of reconstruction has been developing much. After ACL reconstruction, patients are discharged for outpatient treatment. The phase of outpatient rehabilitation has not been sufficiently regulated, methodically developed and practically not controlled by the surgeon. As a result, the effectiveness of rehabilitation and treatment outcomes can be unpredictable.

The purpose of the study was to collect and analyze scientific publications on current methods of restorative treatment of patients after reconstruction of the anterior cruciate ligament of the knee joint.

\section{MATERIAL AND METHODS}

Forty-four sources of information devoted to current methods of rehabilitation for patients after arthroscopic anterior cruciate ligament plasty were analyzed. The search in the bibliographic databases PubMed and Web of Science was conducted using the keywords "anterior cruciate ligament reconstruction", "anterior cruciate ligament rehabilitation", "rehabilitation treatment after reconstruction of the anterior cruciate ligament",

\begin{abstract}
"rehabilitation after plastic surgery of the anterior cruciate ligament." Among the materials studied, there are four Russian-language works and 40 Englishlanguage articles, 10 reviews and 34 original articles among them. Inclusion criteria were compliance with the general theme, relevance, introduction of novel rehabilitation treatments; works published earlier than the last 10 years were excluded.
\end{abstract}




\section{RESULTS}

The main treatment for anterior cruciate ligament injury is surgery. The most popular method of recovery is arthroscopic reconstructive plasty of the anterior cruciate ligament using an autograft from the central third of the patellar ligament, semitendinosus tendon, or peroneus longus tendon [10-14].

As a method of anesthesia during surgery, as a rule, spinal or general combined anesthesia is used [15-17]. The median time for the first patient's verticalization after spinal anesthesia is 24 hours, 12 hours after combined anesthesia $[18,19]$. Traditionally, to create the best arthroscopic view, anterolateral and anteromedial approaches relative to the ligamentum patellae are used $[12,13]$. After diagnostic arthroscopy, the surgeon proceeds to harvesting the autograft, which is subsequently fixed in the canal of the femur using a special suture button, endobutton, and with an interference screw in the canal of the tibia [12]. Although this operation is of minimally invasive nature, complete ACL replacement with the graft in a position close to the anatomical suggests specific features in further management of patients in the postoperative period.

It is assumed that the process of ACL repair after surgery lasts at least for six months and is directly related to blood flow recovery in this area $[20,21]$. Extreme caution should be exercised during this period. Excessive loads on the ligament should be excluded. In this regard, D.V. Fedulova and G.A. Yamaletdinov distinguish four main periods of rehabilitation for patients with ACL injury: early post-operative (1 week), late post-operative (2-4 weeks), functional (5-8 weeks), and recovery (9-24 weeks) [22 ]. In their publication, they emphasize that each of the periods has its own tasks, and the terms of the periods are conditional.

According to a number of sources, ACL finally recovers after 12 months [20, 21, 24], although full functional ability is achieved by 8 months $[6,23]$. Consequently, the compiling of a rehabilitation program should usually be guided by the period of 24-32 weeks, taking into account the periods mentioned above [24].

The question of starting physical activity and the impact of early loads on the operated limb remains being discussed. Based on the terms above which are required for restoration of functional abilties of the ligament $[6$, 23], patient's motor activity should be gradually grow with physical exercises. However, a number of authors argue in their studies that early weight-bearing and the corresponding physical activity have no harmful effects on the course of the rehabilitation period [25, 26]. Thus, N.E. Marshall et al (2018) studied the course of the postoperative period in young athletes after ACL plasty [25]. The authors analyzed 143 clinical cases, all immobilized using orthoses, with complete exclusion of early postoperative loads for up to two months. The course of rehabilitation according to the plan had to last for 12 months. However, about $67 \%$ of young athletes, having a strong desire to return to sports as soon as possible, rejected immobilization ealier than was schedules and started full weight-bearing by the second week after the operation. They returned to full sports activity after six months. The authors concluded that early loading on the operated joint with a properly adjusted rehabilitation program does not cause harmful consequences.

The issue of the functional timing and its effects on the knee joint after surgery was also discussed a review by L.M. Kruse et al (2012), dedicated to functional recovery in patients after ACL rupture [26]. Based on their analysis of a number of studies, the authors came to a conclusion that early activation after ACL plasty has a positive effect on the course of the rehabilitation period, accelerating it. It should also be noted that early activation in the knee joint after the operation does not decrease the range of motion and functional activity of the knee joint.

As an option for early activation and maintenance of the leg muscles tonus in the period of immobilization, patients may use a device for movements in the ankle joint (RF patent No. 144670) [27]. This model consists of a base, a support for the limbs with elements for fixing them, supports for the axis of rotation and a set of calibrated springs. The device may be placed on the floor or fixed to the bed footboard for training muscles in bed. The main movements are flexion and extension in the ankle joint. A set of calibrated springs with a different number of turns allows for load adjustment, thereby maintaining not only muscle tone but also muscle strength. There are some publications on the effectiveness and practical use of this device [28, 29].

Rehabilitation after ACL plasty is based on physical exercises aimed at maintaining muscle tone of the lower limb during its immobilization in the early post-operative period and at restoring joint motion in the subsequent periods.

R.M. Tikhilov and co-authors have published complexes of physical exercises for each of the periods in their manual [20]. They should have the following sequence:

- in the early postoperative period, maintain the tone of the muscles of the leg and thigh in the supine position; 
- in the late postoperative period, passive activation in the knee and hip joints;

- in the functional period, muscle strengthening with resistance exercises;

- in the recovery period, exercising coordination, training in the gym, slow running and squats.

Complexes of physical exercises after ACL plasty include breathing exercises, general strengthening exercises and special exercises for the lower extremities, which should account for $50 \%$ of the total volume of exercises [24]. Special exercises are as follows. In order to maintain the tone of the muscles of the leg and thigh in the early postoperative period, it is recommended to perform active flexion and extension movements in the ankle joint, repeat 30 times every 2 hours; alternate tension and relaxation of the muscles of the anterior and posterior thigh groups, repeat 10-15 times every 2 hours [20]. As passive exercises, it is recommended to perform full extension in the knee joint while sitting on a couch and placing the injured leg with the heel on a nearby chair, or lying in bed; it is also allowed to passively bend the injured leg which suspends from the edge of the bed, controlling it with the healthy leg. This set of passive exercises should be performed 3-4 times a day for 10-15 minutes [24].

In the late postoperative period, active flexion and passive extension of the knee joint, lifting a straight leg while lying or standing, and mobilization of the patella with the hands are added to the above exercises. Each rxercise should be done 10-15 times and the set of them is repeated once or three times a day [20, 24]. Full passive extension in the late rehabilitation period is allowed to be performed with a weight (no more than $1 \mathrm{~kg}$ ), which is placed on the extended knee. Extension is performed at the end of the entire set of exercises for 15 minutes 1-2 times a day [20].

In the functional period, in order to improve mobility in the knee joint and maintain muscle tone, it is recommended to perform resistance exercises such as rubber bandage traction, in supine and standing positions [20]. The complex of such exercises includes flexion in the knee, abduction and adduction of the leg, lifting a straight leg, passive flexion and extension of the knee joint; 10-15 repetitions 2-3 times a day [20]. It is also advised to perform exercises using the back of a chair for doing half-squats and lifts on one leg; 10-12 repetitions three times a day [24].

In the recovery period, exercises with the use of an inflatable balancing cushion or disc are recommended to develop coordination and proprioception $[20,24]$. Coordination exercises, each done for 3-5 minutes, include maintaining balance, standing on two legs, half-squats, lunges backward and sideward [20]. To strengthen the muscles, it is proposed to use traction block simulators from the 13 th week after the operation to do the same set of exercises as in the functional period, but with a certain degree of weights [20].

Rehabilitation doctors advise swimming to patients who have undergone ACL surgery [20, 24], which is allowed from week 6 after the operation. In the pool, patients are advised slow walking, straight leg swings, and leg abduction. Breaststroke swimming is forbidden [20].

Also, it is possible to use the CPM therapy (Continuous Passive Motion) in order to prevent contractures and develop passive movements. Recently, however, this method has not been used much for rehabilitation of patients with ACL injury, since a number of studies showed that its effectiveness is similar to early activation of movements in the knee joint but expenditures associated with the purchase of equipment are high [30-32]. Reduction in pain and soft tissue edema in the knee joint area are among the positive effects of CPM therapy. However, similar results can be achieved with the help of other treatments [33].

As for the other types of physiotherapy used after ACL plasty, their main purpose is to prevent postoperative hypostatic complications and improve muscle tone. It is rational to use them in an inpatient or early outpatient period after the intervention, when the risk of such complications is higher. For prevention of thromboembolic complications, lymphatic drainage massage, magnetotherapy, ultrasound [34, 35 ] and electromyostimulation are recommended in the studies [36]. The basis for the application of the method is the effect of regular electrical impulses on the gastrocnemius muscle that causes its periodic contraction, leading to the activation of the muscle pump, relief of venous stasis in bedridden patients and in the process of limb immobilization. For indirect prevention of thromboembolic complications, the technique is combined with the use of direct anticoagulants, and in some cases, contributes to cessation in their use. Electromyostimulation is used both in the hospital and for home rehabilitation, since the device itself is portable and relatively cheap.

Electrical stimulation can be used in a variety of ways, including for recovery of muscle tone in the thigh and lower leg [20]. So, in the early postoperative period, electromyostimulation with sinusoidally modulated currents may be effective (RF patent No. 2154506) [37]. The main advantage of using this technique is the stimulation of smooth muscle 
contraction and relaxation. Conduction of sinusoidally modulated impulses along muscle fibers is similar to a normal physiological contraction. Thus, the risk of neurogenic and myogenic components of contractures is decreased, and muscle tone is maintained. This method is performed using a 12-channel electrical myostimulator. To create a pulse, two lead electrodes with a hydrophilic pad moistened with water are used. One electrode is applied to the motor points according to the Erb's table, the second is in the projection of the tendon of this muscle. Electrical stimulation is performed with high-frequency (2000-5000 Hz) currents. The period of stimulation alternates with stimulus pauses. The applied current is 2-10 $\mathrm{mA}$, depending on the individual characteristics of the patient (skin, sweating, etc.). Initially, the exposure is $10-12$ minutes ( $2-3$ sessions), then it is gradually increased to 20-30 minutes. This method of maintaining muscle tone can be used in the early postoperative period by low physical activity.

An important part of the rehabilitation of patients after ACL plasty is immobilization of the knee joint with a plaster cast or a functional orthosis. Its purpose is to relieve pain and reduce the risk of damage to the transplanted ligament. The use of a functional orthosis with hinges in this case is much more convenient. It enables to regulate the range of motion in the knee joint, thereby gradually adapting the joint to physical activity [20].

It should be noted that a number of authors believe that refusal from immobilization after ACL plasty does not pose a potential threat $[38,39]$. S. Brandsson et al. (2001) studied the use of immobilizing means in patients after ACL plasty. They conducted a two-year comparative study observing the treatment outcomes in 50 patients. The first group included patients who had to wear a brace for three weeks after surgery, and the second group included patients who did not have bracing. The authors concluded that patients who wore immobilization had fewer complaints of pain and fewer complications in the early postoperative period than the patients who were rehabilitated without bracing. However, there were no differences in terms of knee function or instability throughout the follow-up period. Thus, the authors showed that there is no need to use immobilization after ACL plasty. However, it was suggested that immobilization is important way to reduce pain after surgery and thus improves patient's quality of life [38].

It should also be noted that one of the reasons of pain in the early postoperative period is soft tissue edema caused by impaired lymphatic drainage in the area of the intervention [40]. it is traditionally recommended to use local cooling (an ice pack or frozen gel) for 20 minutes every 2 hours and an elevated position of the limb on the first day after surgery to reduce edema [20]. A number of researchers have successful experience of using lymphatic kinesio taping metrhod in patients who have undergone ACL reconstruction [41, 42]. S. Balki et al. (2016) studied the effect of kinesio taping in males in the early postoperative period after ACL repair [41]. In the experimental group, kinesio taping was with lymphotapes which distal section of the tape was divided into a number of "legs", $0.5-1.0 \mathrm{~cm}$ wide. The duration of the application was no more than 5-7 days. Control assessment performed in the experimental and control groups on the 5th and 10th day after the operation showed that the use of kinesio tapes accelerates the regression of edema around the patella. They perform an immobilizing role by stabilizing the knee joint, reducing the pain syndrome and assist in muscle tone the posterior thigh group [41]. Studies have also shown that soft tissue edema in patients persists for 7-10 days without kinesio tapes, [41]. It should also be noted that the use of ultrasound, magnetotherapy, lymphatic drainage massage, cryotherapy and thermal procedures is relevant to combat edema [20, 42, 43]. A number of foreign authors published studies proving the effectiveness of cryotherapy in comparison with thermal exposure in the rehabilitation of patients after ACL reconstruction $[42,43]$. M. Jawad et al reported in their review (2017) that patients experience a decrease in the severity of pain and soft tissue edema when cryotherapy was used, regardless of the method and devices [42].

In order to relieve pain in the postoperative period, in addition to relieving edema, medication therapy is administered with non-steroid anti-inflammatory drugs (ketorolac), local anesthetics (ropivacaine, lidocaine) or opioids (tramadol). Many authors publish different variants of blockade in patients who have undergone ACL reconstruction, each of which has a positive result [44-46]. M.D. Ivanov et al (2014) compared the effectiveness of iliofascial blockade and prolonged blockade of the femoral nerve in the postoperative period in patients after ACL plasty [44]. A $0.2 \%$ ropivacaine solution was chosen as the anesthetic and was injected slowly, 3-4 ml per hour. As a result, patients' assessment of pain with a visual analogue scale showed that it is much more effective to perform iliofascial blocks. They allow simultaneous blockade of the femoral, obturator, and lateral cutaneous nerves [44]. In turn, Danish anesthesiologists led by K. Lanz (2018) and Italian 
anesthesiologists headed by A.L. Ambrosoli (2019) proved the effectiveness of separate blockades of the obturator and lateral cutaneous nerve of the thigh in patients after ACL reconstruction $[45,46]$.

The average inpatient stay after ACL reconstruction is four to five days. Having a program of further rehabilitative measures in hand, the patient is able to independently undergo rehabilitation at home and visit a specialist to adjust the treatment on an outpatient basis. In 2013 B.W. Brewer et al (2013) published an article in which they proved high effectiveness of rehabilitation programs after ACL surgery at home [48]. The authors reported the highest level $(100 \%)$ of adherence to the prescribed regimen by the participants. It was concluded that there was no difference between the implementation of rehabilitation at home or at hospital. A number of other authors also concluded that the programs they had developed for training at home turned to be understandable, convenient and reliable for patients [23, 49-51].

\section{DISCUSSION}

Our study summarizes a number of relevant components required to develop an effective rehabilitation program. The main issues of the rehabilitation of patients after ACL reconstruction in outpatient settings are a protective regime (wearing a functional orthosis or other immobilizing means, dosed walking with crutches) and physical activity (a set of physical exercises and swimming) $[20,24-26,31]$. Correct tasks according to each rehabilitation period should be fulfilled by the rehabilitation treatment program and stage-by-stage implementation of a complex of physical exercises. It should be noted that early activation of the limb and maintenance of muscle tone are important for fast recovery after ACL plasty. They prevent iatrogenic, myogenic, neurogenic and desmogenic components of contractures [26]. It should also be noted that immobilization should not cause stasis in lower limb blood and lymphatic systems. Therefore, it is desirable that the immobilizing devices allow for a certain range of motion in the knee joint. For this purpose, it is better to use a functional orthosis. This review shows the main current issues of the rehabilitation treatment of patients after ACL reconstruction which enable to develop an effective rehabilitation program [20, 24-26, 31].

\section{CONCLUSION}

Thus, insufficient attention has been paid to the rehabilitation of patients after arthroscopic plasty of the anterior cruciate ligament. The patient leaves the hospital by the end of the early postoperative period and his rehabilitation treatment is performed on an outpatient basis and, as a rule, is not supervised. The emphasis on the use of a certain set of physical exercises, early activation of the limb, dosed walking and effective physiotherapy, including the use of author's devices, accelerate the patient's rehabilitation process.

No conflict of interest has been declared.

\section{REFERENCES}

1. Epifanov A.V., Tseka S.O., Epifanov V.A., Korolev A.V. Vosstanovitelnoe lechenie posle artroskopicheskikh vmeshatelstv na kolennom sustave pri povrezhdeniiakh kapsulno-sviazochnogo apparata [Restorative treatment after arthroscopic interventions on the knee for the capsule-ligamentous system injuries]. M., Avtorskaia Akademiia, 2011, 152 p. (in Russian)

2. Herrington L., Myer G., Horsley I. Task based rehabilitation protocol for elite athletes following anterior cruciate ligament reconstruction: a clinical commentary. Phys. Ther. Sport, 2013, vol. 14, no. 4, pp. 188-198. DOI: 10.1016/j.ptsp.2013.08.001

3. Ithurburn M.P., Paterno M.V., Thomas S., Pennell M.L., Evans K.D., Magnussen R.A., Schmitt L.C. Clinical measures associated with knee function over two years in young athletes after ACL reconstruction. Knee, 2019, vol. 26, no. 2, pp. 355-363. DOI:10.1016/j.knee.2019.01.011

4. Sayampanathan A.A., Howe B.K.T., Bin Abd Razak H.R., Chi C.H., Tan A.H.C. Epidemiology of surgically managed anterior cruciate ligament ruptures in a sports surgery practice. J. Orthop. Surg., 2017, vol. 25, no. 1, pp. 2309499016684289. DOI: 10.1177/2309499016684289

5. Ristić V., Ninković S., Harhaji V., Milankov M. Causes of anterior cruciate ligament injuries. Med. Pregl., 2010, vol. 63, no. 7-8, pp. 541-545. DOI: $10.2298 / \mathrm{mpns} 1008541 \mathrm{r}$

6. Harris J.D., Abrams G.D., Bach B.R., Williams D., Heidloff D., Bush-Joseph C.A., Verma N.N., Forsythe B., Cole B.J. Return to sport after ACL reconstruction. Orthopedics, 2014, vol. 37, no. 2, pp. e103-e108. DOI: 10.3928/01477447-20140124-10

7. Ali A.A., Abdelwahab M.B. Short-term outcome of multi-ligament knee injury among Sudanese patients. Open Access Maced. J. Med. Sci., 2019, vol. 7, no. 9, pp. 1486-1493. DOI: 10.3889/oamjms.2019.282

8. Mackey D.C., Lachance C.C., Wang P.T., Feldman F., Laing A.C., Leung P.M., Hu X.J., Robinovitch S.N. The Flooring for Injury Prevention (FLIP) Study of compliant flooring for the prevention of fall-related injuries in long-term care: A randomized trial. PLoS Med., 2019, vol. 16, no. 6, pp. e1002843. DOI: 10.1371/journal.pmed.1002843

9. Weitz F.K., Sillanpää P.J., Mattila V.M. The incidence of paediatric ACL injury is increasing in Finland. Knee Surg. Sports Traumatol. Arthrosc., 2020, vol. 28, no. 2, pp. 363-368. DOI: 10.1007/s00167-019-05553-9

10. Liechti D.J., Chahla J., Dean C.S., Mitchell J.J., Slette E., Menge T.J., LaPrade R.F. Outcomes and risk factors of rerevision anterior circulate ligament reconstruction: a systematic review. Arthroscopy, 2016, vol. 32, no. 10, pp. 2151-2159. DOI: 10.1016/j.arthro.2016.04.017

11. Lansdown D.A., Riff A.J., Meadows M., Yanke A.B., Bach B.R. Jr. What factors influence the biomechanical properties of allograft tissue for ACL reconstruction? A systematic review. Clin. Orthop. Relat. Res., 2017, vol. 475, no. 10, pp. 2412-2426. DOI: 10.1007/s11999-017-5330-9

12. Śmigielski R., Zdanowicz U., Drwięga M., Ciszek B., Williams A. The anatomy of the anterior cruciate ligament and its relevance to the technique of reconstruction. Bone Joint J., 2016, vol. 98-B, no. 8, pp. 1020-1026. DOI: 10.1302/0301-620X.98B8.37117 
13. Irarrázaval S., Albers M., Chao T., Fu F.H. Gross, arthroscopic, and radiographic anatomies of the anterior cruciate ligament: foundations for anterior cruciate ligament surgery. Clin. Sports Med., 2017, vol. 36, no. 1, pp. 9-23. DOI: 10.1016/j.csm.2016.08.002

14. Ajrawat P., Dwyer T., Whelan D., Theodoropoulos J., Murnaghan L., Bhargava M., Ogilvie-Harris D., Chahal J. A comparison of quadriceps tendon autograft with bone-patellar tendon-bone autograft and hamstring tendon autograft for primary anterior cruciate ligament reconstruction: a systematic review and quantitative synthesis. Clin. J. Sport Med., 2019. DOI: 10.1097/JSM.00000000000000765

15. Zhang L., Tong Y., Li M., Niu X., Zhao X., Lin F., Li Q. Sciatic-femoral nerve block versus unilateral spinal anesthesia for outpatient knee arthroscopy: a meta-analysis. Minerva Anestesiol., 2015, vol. 81, no. 12, pp. 1359-1368.

16. Wojcikiewicz T., El-Boghdadly K. Analgesic strategies for day-case knee surgery. Anaesthesia, 2019, vol. 74, no. 4, pp. 529-533. DOI: 10.1111/ anae. 14583

17. Gebhardt V., Hausen S., Weiss C., Schmittner M.D. Using chloroprocaine for spinal anaesthesia in outpatient knee-arthroscopy results in earlier discharge and improved operating room efficiency compared to mepivacaine and prilocaine. Knee Surg. Sports Traumatol. Arthrosc., 2019, vol. 27, no. 9, pp. 3032-3040. DOI: 10.1007/s00167-018-5327-2

18. Mahan M.C., Jildeh T.R., Tenbrunsel T., Adelman B.T., Davis J.J. Time of return of neurologic function after spinal anesthesia for total knee arthroplasty: mepivacaine vs bupivacaine in a randomized controlled trial. Arthroplast. Today, 2019, vol. 5, no. 2, pp. 226-233. DOI: 10.1016/j. artd.2019.03.003

19. Gomzhina E.A., Geraskov E.V., Ovsiankin A.V., Koriachkin V.A. Effektivnost rannei posleoperatsionnoi reabilitatsii u patsientov posle pervichnogo totalnogo endoprotezirovaniia kolennogo sustava $\mathrm{v}$ zavisimosti ot razlichnykh metodik posleoperatsionnoi analgezii [The effectiveness of early postoperative rehabilitation in patients after the knee primary total arthroplasty depending various techniques of postoperative analgesia]. Russkii Meditsinskii Zhurnal, 2017, vol. 25, no. 13, pp. 953-956. (in Russian)

20. Tikhilov R.M., Trachuk A.P., Bogopolskii O.E., Serebriak T.V. Vosstanovitelnoe lechenie posle rekonstruktsii perednei krestoobraznoi sviazki kolennogo sustava (rukovodstvo dlia patsienta) [Restorative treatment after the knee anterior cruciate ligament reconstruction (Patient manual)]. SPb., 2009, 32 p. (in Russian)

21. Everhart J.S., Sojka J.H., Kaeding C.C., Bertone A.L., Flanigan D.C. The ACL injury response: A collagen-based analysis. Knee, 2017, vol. 24, no. 3, pp. 601-607. DOI:10.1016/j.knee.2017.01.013

22. Fedulova D.V., Iamaletdinova G.A. Sravnitelnyi analiz programm lechebnoi gimnastiki posle artroskopicheskoi rekonstruktsii perednei krestoobraznoi sviazki [A comparative analysis of therapeutic physical training after arthroscopic reconstruction of the anterior cruciate ligament]. Materialy XX Vseros. Nauch.-prakt. Konf. Gumanitarnogo Un-ta "Rossiia mezhdu modernizatsiei i arkhaizatsiei: 1917-2017 gg." [Proceedings of XX All-Russian Scientific-and-Practical Conference of the Humanitarian University "Russia between Modernization and Archaization: 19172017”.]. Ekaterinburg, 2017, vol. 2, pp. 459-464. (in Russian)

23. Krolikowska A., Sikorski L., Czamara A., Reichert P. Effects of postoperative physiotherapy supervision duration on clinical outcome, speed, and agility in males 8 months after anterior cruciate ligament reconstruction. Med. Sci. Monit., 2018, vol. 24, pp. 6823-6831. DOI: 10.12659/ MSM.912162

24. Kochetkov A.V., Kochuneva O.Ia., Ruleva L.V., compilers. Kinezoterapiia v reabilitatsii patsientov posle plastiki perednei krestoobraznoi sviazki kolennogo sustava: metod. posobie [Kinesitherapy in the rehabilitation of patients after the knee anterior cruciate ligament plasty: teaching aid]. M., 2013,30 p. (in Russian)

25. Marshall N.E., Keller R.A., Dines J., Bush-Joseph C., Limpisvasti O. Current practice: postoperative and return to play trends after ACL reconstruction by fellowship-trained sports surgeons. Muskuloskelet. Surg., 2019, vol. 103, no. 1, pp. 55-61. DOI:10.1007/s12306-018-0574-4

26. Kruse L.M., Gray B., Wright R.W. Rehabilitation after anterior cruciate ligament reconstruction: a systematic review. J. Bone Joint Surg. Am., 2012, vol. 94, no. 19, pp. 1737-1748. DOI: 10.2106/JBJS.K.01246.

27. Aidarov V.I., Takhavieva F.V., Pankov I.O., Emelin A.L. Ustroistvo dlia razrabotki dvizhenii v golenostopnom sustave i myshts stopy i goleni [The device to train movements in the ankle, as well as to train the foot and leg muscles]. Patent RF, no. 144670, A 61H 1/02, 2014. (in Russian)

28. Pankov I.O., Aidarov V.I., Skvortsov A.P. Predotvrashchenie razvitiia ekvinusnoi deformatsii stopy u detei i podrostkov pri lechenii perelomov oblasti kolennogo sustava [Prevention of equinus foot development in children and adolesents when treating fractures in the knee zone]. "Meditsinskaia Pomoshch pri Travmakh: novoe v organizatsii i tekhnologiiakh": Sb. tez. 2-go Vseros. Kongr. po Travmatologii s mezhdunar. uchastiem ["Medical Aid for Injuries: New in Organizing and Technology": Proceedings of II All-Russian Congress in Traumatology with international participation]. SPb., 2017, pp. 73. (in Russian)

29. Krasilnikov V.I., Aidarov V.I., Maleev V.I. Kompleksnoe issledovanie okazaniia meditsinskoi pomoshchi postradavshim s avtodorozhnymi travmami v usloviiakh mnogoprofilnoi kliniki: monografiia [A comprehensive study of providing medical care to the victims of traffic injuries in a multidisciplinary clinic]. Kazan, 2017, 212 p. (in Russian)

30. Wright R.W., Preston E., Fleming B.C., Amendola A., Andrish J.T., Bergfeld J.A., Dunn W.R., Kaeding C., Kuhn J.E., Marx R.G., McCarty E.C., Parker R.C., Spindler K.P., Wolcott M., Wolf B.R., Williams G.N. A systematic review of anterior cruciate ligament reconstruction rehabilitation: part I: continuous passive motion, early weight bearing, postoperative bracing, and home-based rehabilitation. J. Knee Surg., 2008, vol. 21, no. 3, pp. 217-224. DOI: $10.1055 / \mathrm{s}-0030-1247822$

31. Andrade R., Pereira R., Van Cingel R., Staal J.B., Espregueira-Mendes J. How should clinicians rehabilitate patients after ACL reconstruction? A systematic review of clinical practice guidelines (CPGs) with a focus on quality appraisal (AGREE II). Br. J. Sports Med., 2020, vol. 54, no. 9 , pp. 512-519. DOI: 10.1136/bjsports-2018-100310

32. Chang N.-J., Lee K.-W., Chu C.-J., Shie M.-Y., Chou P.-H., Lin C.-C., Liang P.-I. A preclinical assessment of early continuous passive motion and treadmill therapeutic exercises for generating chondroprotective effects after anterior cruciate ligament rupture. Am. J. Sports Med., 2017, vol. 45, no. 10, pp. 2284-2293. DOI: 10.1177/0363546517704847

33. Jaspers T., Taeymans J., Hirschmüller A., Baur H., Hilfiker R., Rogan S. Kontinuierliche passive Bewegungsschiene verbessert den Bewegungsumfang, Schmerz und Schwellung bei ACL-Rekonstruktion: Eine systematische Literaturübersichtsarbeit und Metaanalyse [Continuous passive motion does improve range of motion, pain and swelling after ACL reconstruction: a systematic review and meta-analysis]. Z. Orthop. Unfall., 2019, vol. 157, no. 3, pp. 279-291. (in German) DOI: 10.1055/a-0710-5127

34. Min Z.H., Zhou Y., Jing L., Zhang H.-m., Wang S., Chen W.-h., Chen P.-q. [Case-control study on Chinese medicine fumigation and massage therapy for the treatment of knee stability and functional recovery after anterior cruciate ligament reconstruction operation]. Zhongguo Gu Shang, 2016, vol. 29 , no. 5, pp. 397-403. (in Chinese)

35.Zalta J. Massage therapy protocol for post-anterior cruciate ligament reconstruction patellofemoral pain syndrome: a case report. Int. J. Ther. Massage Bodywork, 2008, vol. 1, no. 2, pp. 11-21. DOI: 10.3822/ijtmb.v1i2.22

36. Ziatdinov B.G., Akhtyamov I.F, Sadykov R.I. Sovremennye vozmozhnosti profilaktiki tromboembolicheskikh oslozhnenii pri endoprotezirovanii krupnykh sustavov nizhnikh konechnostei [Modern possibilities of preventing thromboembolic complications in arthroplasty of the lower limb large joints]. Prakticheskaia Meditsina, 2015, no. 4-1, pp. 66-70. (in Russian)

37. Aidarov V.I., Skvortsov A.P. Sposob profilaktiki kontraktur [The way of preventing contractures]. Patent RF, no. 2154506, A 61N 1/36, 1997. (in Russian)

38. Brandsson S., Faxén E., Kartus J., Eriksson B.I., Karlsson J. Is a knee brace advantageous after anterior cruciate ligament surgery? A prospective, randomized study with a two-year follow-up. J. Med. Sci. Sports, 2001, vol. 11, no. 2, pp. 110-114. DOI: 10.1034/j.1600-0838.2001.011002110.x

39. Möller E., Forssblad M., Hansson L., Wange P., Weidenhielm L. Bracing versus nonbracing in rehabilitation after anterior cruciate ligament reconstruction: a randomized prospective study with 2-year follow-up. Knee Surg. Sports Traumatol. Arthrosc., 2001, vol. 9, no. 2, pp. $102-108$. DOI: $10.1007 / \mathrm{s} 001670000192$

40. Balki S., Göktas H.E. Short-term effects of the Kinesio Taping ${ }^{\circledR}$ on early postoperative hip muscle weakness in male patients with hamstring autograft or allograft anterior cruciate ligament reconstruction. J. Sport. Rehabil., 2019, vol. 28, no. 4, pp. 311-317. DOI: 10.1123/jsr.2017-0219 
41. Balki S., Göktaş H.E., Öztemur Z. Kinesio taping as a treatment method in the acute phase of ACL reconstruction: A double-blind, placebocontrolled study. Acta Orthop. Traumatol. Turc., 2016, vol. 50, no. 6, pp. 628-634. DOI: 10.1016/j.aott.2016.03.005

42. Jawad M., Sodhi N., Chughtai M., Newman J.M., Khlopas A., Bhave A., Wagner T., Sultan A.A., Roche M., Mont M.A. Cryotherapy treatment after arthroscopic knee debridement and ACL reconstruction: a review. Surg. Technol. Int., 2017, vol. 30, pp. 415-424.

43. Song M., Sun X., Tian X., Zhang X., Shi T., Sun R., Dai W. Compressive cryotherapy versus cryotherapy alone in patients undergoing knee surgery: a meta-analysis. Springerplus, 2016, vol. 5, no. 1, pp. 1074. DOI: 10.1186/s40064-016-2690-7

44. Ivanov M.D., Zabolotskii D.V., Kulev A.G., Ulrikh G.E., Velichko K.E., Kozyrev A.S. Artroskopicheskaia plastika perednei krestoobraznoi sviazki u podrostkov. Chto vybrat anesteziologu? [Arthrosopic plasty of the anterior cruciate ligament in adolescents. What should an anesthesiologist choose?]. Travmatologiia i Ortopediia Rossii, 2014, no. 1, pp. 59-64. (in Russian)

45. Lenz K., Jensen K., Tanggaard K., Vazin M., Bendtsen T.F., Chan V., Krogsgaard M.R., Strube M.L., Børglum J. Comparing low volume saphenousobturator block with placebo and femoral-obturator block for anterior cruciate ligament reconstruction. Minerva Anestesiol., 2018, vol. 84, no. 2, pp. 168-177. DOI: 10.23736/S0375-9393.17.11718-9

46. Ambrosoli A.L., Guzzetti L., Severgnini P., Fedele L.L., Musella G., Crespi A., Novario R., Cappelleri G. Postoperative analgesia and early functional recovery after day-case anterior cruciate ligament reconstruction: a randomized trial on local anesthetic delivery methods for continuous infusion adductor canal block. Minerva Anestesiol., 2019, vol. 85, no. 9, pp. 962-970. DOI: 10.23736/S0375-9393.19.13474-8

47. Bischoff L., Babisch C., Babisch J.. Layher F., Sander K., Matziolis G., Pietsch S., Röhner E. Effects on proprioception by Kinesio taping of the knee after anterior cruciate ligament rupture. Eur. J. Orthop. Surg. Traumatol., 2018, vol. 28, no. 6, pp. 1157-1164. DOI: 10.1007/s00590-018-2167-1

48. Brewer B.W., Cornelius A.E., Van Raalte J.L., Tennen H., Armeli S. Predictors of adherence to home rehabilitation exercises following anterior cruciate ligament reconstruction. Rehabil. Psychol., 2013, vol. 58, no 1, pp. 64-72. DOI: 10.1037/a0031297

49. Grant J.A., Mohtadi N.G., Maitland M.E., Zernicke R.F. Comparison of home versus physical therapy supervised rehabilitation programs after anterior cruciate ligament reconstruction: a randomized clinical trial. Am. J. Sports Med., 2005, vol. 33, no. 9, pp. 1288-1297. DOI: 10.1177/0363546504273051

50. Lim J.M., Cho J.J., Kim T.Y., Yoon B.C. Isokinetic knee strength and proprioception before and after anterior cruciate ligament reconstruction: A comparison between home-based and supervised rehabilitation. J. Back Musculoskelet. Rehabil., 2019, vol. 32, no. 3, pp. 421-429. DOI: 10.3233/ BMR-181237

51. Lobb R., Tumilty S., Claydon L.S. A review of systematic reviews on anterior cruciate ligament reconstruction rehabilitation. Phys. Ther. Sport., 2012, vol. 13, no. 4, pp. 270-278. DOI: 10.1016/j.ptsp.2012.05.001

Received: 06.02.2020

\section{Information about the authors:}

1. Ildar F. Akhtyamov, M.D., Ph.D., Professor, Kazan State Medical University, Kazan, Russian Federation, Email: yalta60@mail.ru

2. Vladimir I. Aidarov, M.D., Ph.D.,

Republican Clinical Hospital, Kazan, Russian Federation,

Email: aidarov_vladimir@mail.ru

3. Eldar R. Khasanov, M.D.,

Kazan State Medical University, Kazan, Russian Federation 